\title{
KONSEP MANUSIA BARU DI DALAM KRISTUS BERDASARKAN SURAT EFESUS 4:17-32
}

\author{
Hendi \& Tiopan Aruan \\ Sekolah Tinggi Teologi Soteria Purwokerto \\ Jl. Raya Barat, Ketenger, Kec. Baturraden, Kab. Banyumas, Jawa Tengah \\ Email: hendi@sttsoteria.ac.id
}

\begin{abstract}
The Concept of a New Man in Christ Based on Ephesians 4:17-32. This article discusses the new man in Christ through a syntactic and semantic approach to text analysis, namely the focus on the text itself, interactions with other texts, and the writings of the Church Fathers. Only those who wear the new humanity that comes from Christ can become new human. The new human consists of soul and body which is in the new humanity. Humanity in Christ is the humanity of Adam renewed by Christ by dying on the cross, buried, and rising from the dead so that Christ has provided a new container that is humanity universally new. This new humanity is universal salvation which is a kind of clothing for every individual. Wearing new humanity or Christ's clothes becomes individual salvation. When we wear the clothes of Christ, we become new people so that our souls and bodies or our whole lives are in the new humanity. The soul and body that is in this new humanity are now continuing to process or be renewed towards a soul and body like Christ. How? That is fighting sin and doing love both spiritually and physically.
\end{abstract}

Keywords: nous, new human, soul, spirit, Christ

\begin{abstract}
Abstrak: Konsep Manusia Baru Di dalam Kristus Berdasarkan Surat Efesus 4:17-32. Artikel ini membahas tentang manusia baru di dalam Kristus melalui pendekatan analisis teks secara sintaksis dan semantis yaitu fokus pada teks itu sendiri, interaksi dengan teks-teks lain dan tulisan para Bapa Gereja. Hanya orang Kristen yang mengenakan kemanusiaan baru yang berasal dari Kristus yang dapat menjadi manusia baru. Manusia baru terdiri dari jiwa dan tubuh yang berada di dalam kemanusiaan baru. Kemanusiaan di dalam Kristus adalah kemanusiaan Adam yang diperbarui oleh Kristus dengan jalan Yesus mati di atas kayu salib, dikubur, dan bangkit dari kematian sehingga Kristus telah menyediakan suatu wadah baru yaitu kemanusiaan baru secara universal kepada manusia. Kemanusiaan baru adalah keselamatan universal yang menjadi semacam pakaian untuk dikenakan bagi setiap individu. Memakai kemanusiaan baru atau pakaian Kristus menjadi keselamatan individu. Ketika orang Kristen mengenakan pakaian Kristus dan menjadi manusia baru, sehingga jiwa dan tubuh serta seluruh hidup ada di dalam kemanusiaan baru. Jiwa dan tubuh yang ada di dalam kemanusiaan baru ini sekarang terus berproses atau diperbarui menuju jiwa dan tubuh seperti Kristus. Bagaimana caranya? Yaitu melawan dosa dan melakukan kasih baik secara jiwai dan badani.
\end{abstract}

Kata kunci: nous, manusia baru, jiwa, roh, Kristus

\section{PENDAHULUAN}

Banyak orang Kristen beranggapan bahwa setelah dibaptis secara ritual di gereja otomatis sudah menjadi orang yang telah diselamatkan. Padahal menjadi Kristen tidak hanya sekedar dibaptis dan diselamatkan. Melainkan ada konsekuensi setelah dibaptis dan menjadi orang Kristen adalah menyempurnakan gambar Allah di dalam dirinya yaitu menjadi manusia baru di dalam Kristus yang terus disempurnakan sampai menjadi serupa dengan Kristus
(1 Yoh 3:2-3). Orang Kristen yang percaya Yesus dan mengalami pembaharuan didalam Kristus adalah manusia baru, bukan hanya sekedar beragama Kristen, tetapi ada pembaharuan didalam hidup. Tony Evans (1996, p.22) menjelaskan dalam penelitiannya menyatakan bahwa banyak orang mengaku Kristen hanya karena sudah dibaptis, tetapi tidak menunjukkan perubahan hidup. Sebab itu, setiap orang Kristen perlu menyadari bahwa dirinya adalah manusia baru di dalam Kristus. Namun apa maksudnya menjadi 
manusia baru di dalam Kristus? Dan bagaimana menghidupi manusia baru tersebut? Paparan tulisan ini akan mencoba untuk menjawab pertanyaanpertanyaan ini.

Topik manusia baru di dalam Kristus akan dibahas dari perspektif surat Efesus 4:17-32 yang ditulis oleh Rasul Paulus. Topik ini secara doktrinal dan etika sangat penting sesuai paparan permasalahan di atas. Ada beberapa alasan pentingnya terkait topik di atas, sehingga diuraikan dengan singkat di bawah ini.

Manusia baru ibarat seperti pakaian baru. Orang Kristen menanggalkan pakaian lama yaitu kehidupan lama dan mengenakan manusia baru yaitu jiwa dan tubuh yang baru di dalam Kristus. Manusia baru adalah jiwa dan tubuh yang telah diperbarui oleh Kristus sejak percaya atau beriman kepada Kristus dan dibaptis yaitu ikut bersama Kristus mati, dikubur, dan bangkit dari kematian sehingga jiwa dan tubuh ikut diperbarui. Jiwa yang dahulu mati sekarang bangkit dan tubuh yang dikenakan sekarang menjadi bait Allah dan pada akhirnya akan mengenakan tubuh atau daging yang mulia seperti tubuh kemuliaan Kristus. Itulah manusia baru yang menjadi identitas orang percaya sekarang.

Orang percaya adalah anak-anak Allah yang dilahirkan dari air dan Roh yaitu melalui baptisan yang dikerjakan oleh Roh Kudus. Ada benih ilahi yang ditanamkan di dalam hati. Benih itu adalah hasil benih iman dan anugerah ilahi yaitu kasih penebusan Kristus atas dosa, kematian, dan iblis dengan jalan mati disalib, dikubur, dan bangkit dari kematian.

Benih itu ada di dalam manusia baru atau ciptaan baru di dalam Kristus sehingga disebut anakanak Allah karena Kristus. Benih itu akan bertumbuh menghasilkan buah. Benih itu adalah manusia baru yang sejati secara batiniah dan lahiriah. Orang percaya adalah manusia rohani yang terdiri atas manusia batiniah yang telah dihidupkan di dalam baptisan dan manusia lahiriah yang menjadi bait Allah.
Manusia rohaniah atau manusia baru sedang membentuk atau memproses baik manusia lahiriah dan batiniah. Ibarat seorang ibu yang mengandung, kata Rasul Paulus orang percaya sedang mengandung sampai rupa Kristus menjadi nyata di dalam diri, baik secara batiniah dan lahiriah. Secara lahiriah akan memakai tubuh kemuliaan seperti tubuh kemuliaan Kristus. Secara batiniah akan menjadi manusia terang yang bercahaya seperti transfigurasi Kristus. Itulah orang percaya yang sejati yang sedang dibentuk dalam benih ilahi, sehingga ada tugas yang wajib dikerjakan atau kelola bersama Roh Kudus agar semakin serupa Kristus (1 Yoh 3:2). Dan sekarang setiap orang percaya sedang mengerjakan tugas dan berupaya untuk menemukan jati diri yang sejati yaitu serupa Kristus. Jiwa manusia batiniah dan tubuh manusia lahiriah yang ada di dalam diri orang percaya sekarang telah ditanam benih ilahi sehingga jiwa dan tubuh, sekarang sedang dibentuk menjadi serupa Kristus. Serupa dengan Kristus itulah tujuan hidup orang percaya, sehingga kehidupan yang sedang dihidupi merupakan proses menuju keserupaan dengan Kristus.

Yohanes Pembaptis berkata bahwa aku semakin kecil Kristus semakin besar. Ini artinya orang percaya sedang berjuang menemukan jati diri, dengan mematikan kehidupan yang lama dan menghidupkan kehidupan yang baru yang serupa Kristus. Dari gambar Allah berproses menjadi rupa Allah. Dari benih berproses menjadi buah. Dari jiwa yang mati menjadi jiwa yang hidup. Dari tubuh yang fana menjadi tubuh yang mulia. Dari kefanaan mengalami transfigurasi. Menanggalkan manusia lama memakai manusia baru. Dari sifat kekanak-kanakan menuju kedewasaan ke arah Kristus. Dari gelap menuju terang menjadi manusia bercahaya. Dari manusia duniawi menjadi manusia ilahi atau rohani.

Dengan mengenakan atau memakai manusia baru setiap orang percaya dapat memuliakan Allah dengan melakukan apa yang menjadi kehendak Allah. Tanpa mengenakan manusia baru maka tidak akan bisa memuliakan Allah melalui kehidupannya. Seperti yang dituliskan oleh Zuck dan Bock (2011, 
p. 354) bahwa orang yang telah menerima kuasa rohani yang dapat mengaplikasikan kehidupan yang memuliakan Allah. Hal yang sama juga diperjelas oleh Hengki Wijaya (2016, p.110) bahwa natur orang percaya menjadi manusia baru adalah sekali untuk selama-lamanya, namun proses untuk menjadi manusia baru adalah peristiwa yang terus-menerus diperbarui untuk serupa dengan gambar-Nya yang sesuai dengan kehendak-Nya. Faktanya orang percaya memiliki status manusia baru yang menjalani kehidupan manusia baru. Implikasi teologis pengenaan manusia baru dalam Kristus adalah orang percaya terus-menerus diperbarui oleh Roh Kudus untuk menjadi ciptaan yang baru yang serupa dengan gambar-Nya. Roh Kudus memeteraikan orang percaya dan mengerjakan keselamatan orang percaya menjadi manusia baru. Implikasi praktis pengenaan manusia baru dalam Kristus adalah tanggung jawab orang percaya yang memahami status baru di dalam Kristus untuk menyatakan kebenaran, menjadi berkat bagi orang lain, menyenangkan Roh Kudus dan mengenakan kasih di dalam Kristus. Corey Keating (2003, p.4) juga menyatakan bahwa hanya dalam kehidupan manusia baru terlihat kehidupan yang dapat memuliakan Allah.

Selain memuliakan Allah, mengenakan manusia baru berarti membentuk atau melukiskan kembali gambar Allah di dalam diri yang rusak menjadi gambar Anak-Nya yaitu Yesus Kristus. Manusia kembali kepada kebenaran dan kekudusan yang sesungguhnya di mana jiwa dan roh manusia dibarui. Hendi (2016, p. 46) menjelaskan Nous dibarui membuat roh orang percaya menjadi roh yang baru sehingga orang percaya memiliki kodrat baru yakni manusia yang kembali kepada kebenaran dan kekudusan yang sesungguhnya (Ef 4:24). Kembali kepada ciptaan Allah dalam Kristus Yesus (Ef 2:10) sebagai gambar dan rupa Allah yang sempurna.

Darius dan Robby Panggara (2013, p. 29) juga menyimpulkan dalam dalam artikelnya tentang manusia baru: pertama, manusia lama adalah manusia yang berjalan berdasarkan pengertiannya sendiri, tidak mengenal Allah, memiliki pikiran yang sia-sia, pengertiannya digelapkan, jauh dari hidup persekutuan dengan Allah, memiliki hati yang degil, hati tumpul, sehingga menyerahkan dirinya kepada hawa nafsu dan mengerjakan dengan serakah segala macam kecemaran. Kedua, manusia baru adalah manusia yang telah diciptakan menurut kehendak Allah di dalam kebenaran dan kekudusan, di mana orangorang yang percaya kepada Kristus memiliki kedudukan baru yaitu dari kebinasaan dipindahkan kepada hidup yang kekal dan manusia yang terus diperbaharui serta dipersatukan dengan Kristus. Ketiga, sebagai manusia baru di dalam Kristus, orang percaya tidak lagi menjadi senjata-senjata kelaliman tetapi sebaliknya menjadi senjata-senjata kebenaran dan hidup memuliakan Allah.

Berdasarkan uraian di atas maka artikel ini akan membahas tentang konsep manusia baru di dalam Kristus menurut teks Efesus 4:17-32. Tujuannya adalah untuk memaparkan siapa manusia baru itu dan cara hidup yang sesuai dengan manusia baru di dalam Kristus.

\section{METODE}

Data diperoleh dari teks surat Efesus 4:1732 yang diambil dari The Greek New Testament Nestle-Aland 28th Edition of the Greek New Testament). Analisis data atau teks akan menggunakan metode eksposisi yaitu menguraikan atau memaparkan teks untuk menemukan semantic content (isi semantis atau makna spiritual dibalik teks atau Theoria) di dalam teks-teks tersebut dengan fokus pada teks itu sendiri dan berinteraksi dengan teksteks lain yang berhubungan semantis atau makna (Hendi, 2014, p.129-34).

Semantic Content dibangun dari historia dengan cara membuat syntactic form (struktur teks dalam bahasa Yunani) dan terjemahan literal untuk mendapatkan poin-poin sintaksis. Selanjutnya poinpoin sintaksis akan dianalisis ke dalam semantic content dengan berinteraksi pada teks-teks lain di dalam Alkitab dan tulisan para Bapa Gereja.

Semantic content bersifat Christ-centered dan Ecclesial (Ware, 2008, p. 5742). Christ-centered 
berarti ajaran atau doktrin atau didaskalia yang berpusat kepada Kristus. Ecclesial berarti didaskalia yang berpusat pada Tradisi atau Paradosis Gereja yang dimulai dari para Rasul dan Bapa-bapa Gereja baik secara lisan dan tulisan. Didaskalia Kristus dan dilanjutkan dalam bentuk Paradosis Gereja merupakan warisan kekayaan doktrin yang begitu berharga dan berlimpah bagi kekristenan sampai sekarang. Tulisan Bapa-bapa Gereja adalah salah satu Para- dosis Gereja yang akan dipakai untuk melengkapi doktrin yang Christ-centered.

Kemudian kajian di dalam semantic contenta kan diringkas atau dirumuskan menjadi konsep teologis (personal). Konsep teologis ini adalah doktrin atau ajaran yang ditemukan dan kemudian akan dibuat relevansi atau aplikasinya bagi kehidupan spiritual orang percaya berdasarkan doktrin tersebut (obedience).

\section{HASIL \& PEMBAHASAN}

\section{Historia: Data Teks}

\section{Teks dan Syntactic Form}

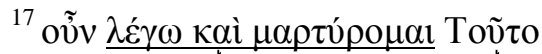

$\longrightarrow \dot{\varepsilon} v \kappa v p i ́($,

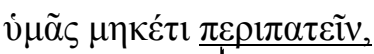

$\longrightarrow \kappa \alpha \theta \grave{\omega} \varsigma \underline{\kappa} \alpha \grave{\imath} \tau \grave{\alpha}$ है $\theta v \eta \pi \varepsilon \rho 1 \pi \alpha \tau \varepsilon \tilde{\imath}$

${ }^{18}$ öv $\tau \varepsilon \varsigma$,

$\rightarrow \dot{\varepsilon} v \mu \alpha \tau \alpha \iota o^{\tau} \eta \tau \imath \tau o \tilde{v}$ voò

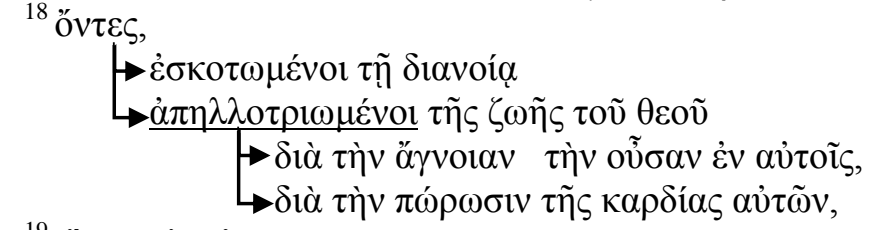

${ }^{19}$ oĩ $\tau 1 v \varepsilon \varsigma \dot{\alpha} \pi \eta \lambda \gamma \eta \kappa o ́ \tau \varepsilon \varsigma$

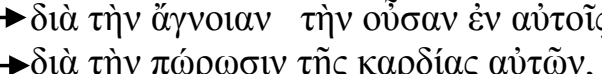

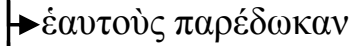

$\rightarrow \tau \tilde{n} \alpha \dot{\alpha} \sigma \varepsilon \lambda \gamma \varepsilon i \underline{\alpha}$

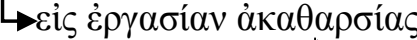

${ }^{20} \delta \grave{\varepsilon}$

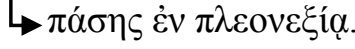

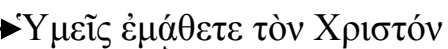

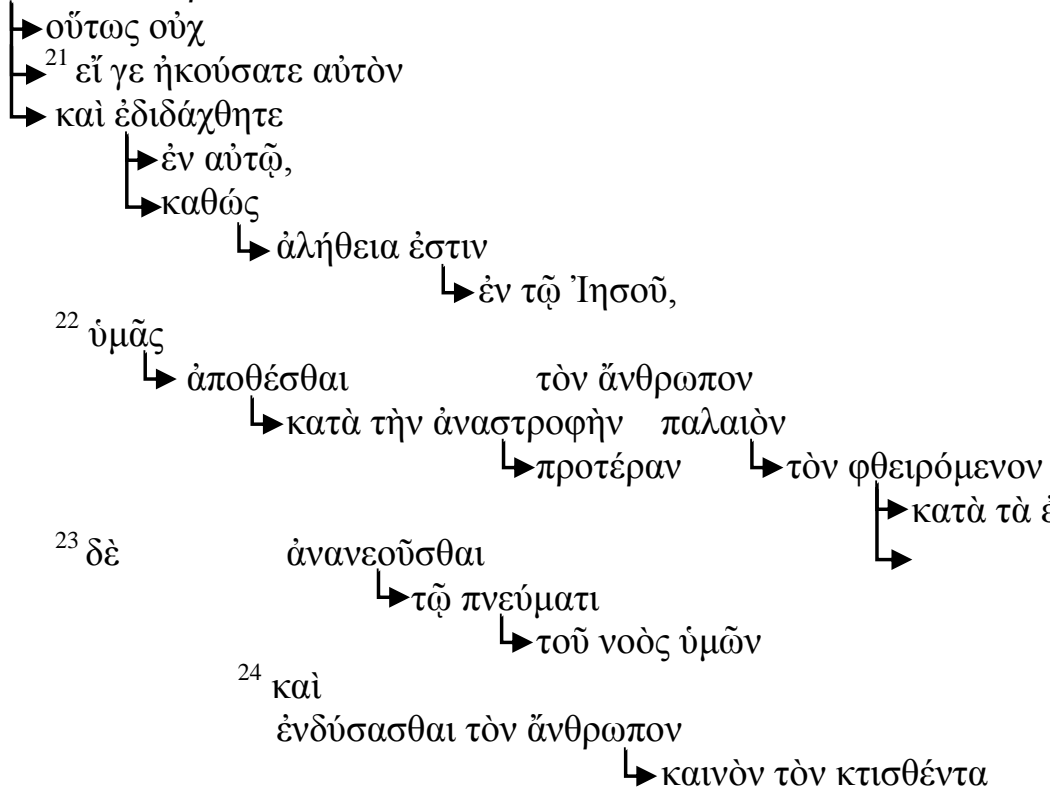

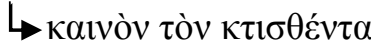




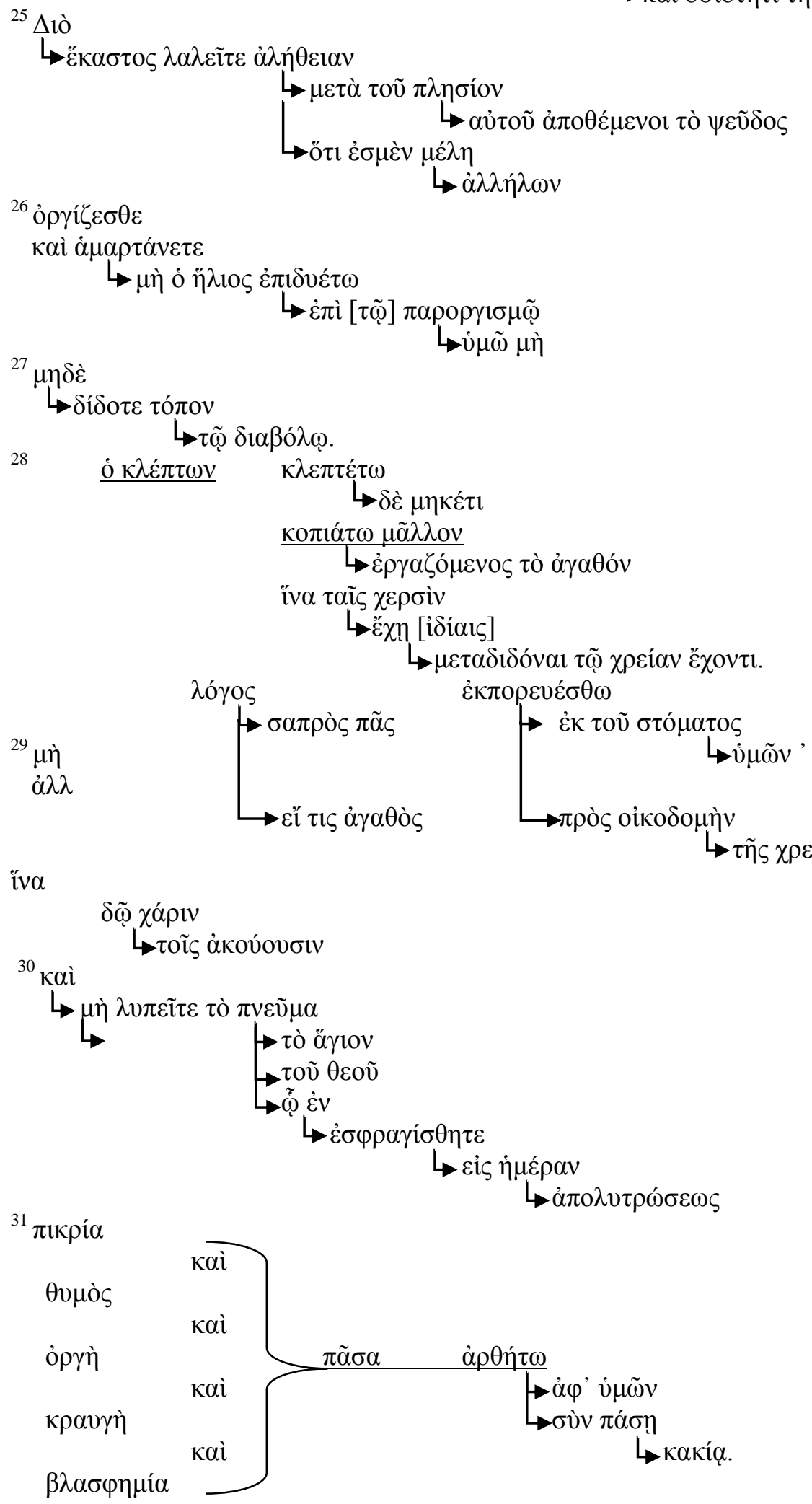


${ }^{32}[\delta \grave{\varepsilon}]$

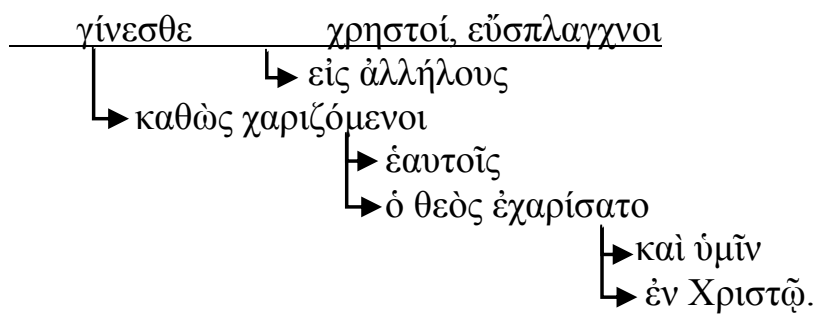

\section{Terjemahan Literal}

${ }^{17}$ Ini aku katakan, sehingga, dan saksikan di dalam Tuhan supaya kamu tidak lagi berjalan sama seperti mereka yang tidak percaya, di dalam nous mereka yang sia-sia, ${ }^{18}$ mereka telah digelapkan oleh pikiran/dianoia mereka, terasing dari Allah karena kebodohan yang ada di dalam mereka dan kekerasan hati mereka, ${ }^{19}$ yang perasaan mereka yang tumpul mereka menyerahkan diri mereka sendiri kepada hawa nafsu untuk perbuatan semua kecemaran dalam keserakahan. ${ }^{20}$ Tetapi kamu pelajari Kristus tidaklah demikian, ${ }^{21}$ jika memang kamu mendengar Dia dan diajar di dalam Dia seperti kebenaran ada di dalam Yesus, ${ }^{22}$ yaitu kamu, menurut perbuatan dahulu, menanggalkan manusia lama yang membawa kepada kebinasaan menurut hawa nafsu yang menyesatkan, ${ }^{23}$ dan diperbarui di dalam roh dari nous $\mathrm{kamu}^{24}$ dan mengenakan manusia baru yang diciptakan menurut Allah di dalam kebenaran dan kekudusan yang sebenar-nya. ${ }^{25}$ Karena itu, setiap orang buanglah dusta dan bicaralah kebenaran kepada tetangganya karena kita adalah sesama anggota. ${ }^{26}$ Kamu marah tetapi jangan berbuat dosa; janganlah matahari terbenam sebelum padam amarahmu, ${ }^{27}$ dan jangan beri kesempatan kepada iblis. ${ }^{28}$ Orang yang mencuri janganlah lagi mencuri, tetapi biarlah ia bekerja keras dan melalui tangannya melakukan pekerjaan baik, supaya ia dapat berbagi sesuatu kepada orang yang berkekurang-an. ${ }^{29}$ Jangan biarkan ada perkataan kotor keluar dari mulut kamu; tetapi gunakan semua perkataan yang baik di mana perlu untuk saling membangun supaya mereka yang mendengarnya memperoleh kasih karunia. ${ }^{30}$ Dan jangan mendukakan Roh Kudus Alah, yang telah memeteraikan kamu menjelang hari penyelamatan.
${ }^{31}$ Segala kepahitan dan kegeraman dan kemarahan dan pertikaian dan fitnah; hendaklah dibuang dari kamu dengan semua kejahatan. ${ }^{32}$ Tetapi berbuat baiklah seorang terhadap yang lain, penuh kasih sayang dan saling mengampuni, seperti Allah mengampuni kamu di dalam Kristus.

\section{Theoria: Semantic Content}

\section{Semantic Points (Penjelasan Setiap Ayat)}

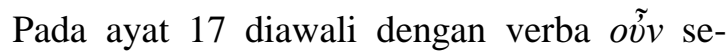
hingga, yang menunjukkan bahwa teks ini bukanlah konklusi yang dituliskan rasul Paulus kepada jemaat-jemaat di Efesus melainkan merujuk kembali kepada perkataannya yang dulu kepada jemaat yang sama yang tertulis di dalam pasal 4:1. Selanjutnya

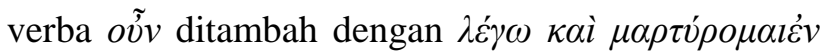

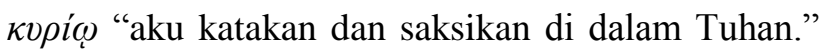
Rasul Paulusberkata karena ada dorongan dari Yesus Kristus. dengan kata lain bahwa Rasul Paulus hanya mewakili Tuhan untuk mengatakannya (Bratcher dan Nida, 1982, p.110). Ini adalah desakan bukan perintah (Abineno, 1993, p.146). Apa desakannya? Desakannya ialah bahwa jemaat Efesus tidak lagi hidup dengan nous yang sia-sia dan digelapkan oleh dianoia. Jemaat telah mempelajari Kristus dan mendengar Dia.

Berbeda dengan orang yang belum mempelajari Kristus (Ef 4:18-19): nous mereka sia-sia; dianoia atau pikiran mereka gelap; terasing dari Allah; perasaan mereka yang tumpul; mereka menyerahkan diri mereka sendiri kepada hawa nafsu untuk perbuatan semua kecemaran dalam keserakahan. Hal ini disebab-kan oleh kebodohan dan kekerasan hati mereka yaitu tidak mendengar Kristus dan 
diajar di dalam Dia. Mereka gagal menghormati Allah dan tidak mau mengenal Allah (Martin, 1990, p.101) sehingga kehidupan mereka tidak memuliakan Allah. Orang-orang seperti ini adalah orangorang yang tidak lagi mempunyai perasaan. Perasaan atau batin mereka sudah tumpul sehingga yang mereka lakukan hanyalah kecemaran, bertindak karena hawa nafsu semata dan menjadi serakah.

Jemaat Efesus adalah manusia baru dan mereka yang tidak mengenal Kristus adalah manusia lama. Jemaat telah mendengar Kristus dan diajar di dalam Kristus dalam kehidupan mereka (Ef 4:2024). Ayat 20 diawali dengan konjungsi $\delta \dot{\varepsilon}$ "tetapi" merupakan kalimat kontras dari kalimat sebelumnya (ayat 17-19). Manusia baru adalah mereka yang telahmenanggalkan manusia lama yang membawa kepada kebinasaan menurut hawa nafsu yang menyesatkan. Manusia baru adalah manusia yang telah diperbarui di dalam roh dari nous. Manusia baru adalah manusia yang diciptakan menurut Allah di dalam kebenaran dan kekudusan yang sebenarnya. Kemudian Rasul Paulus memberikan satu rangkaian konsekuensi $\Delta$ iò (ayat 25-32) dari manusia baru yang diciptakan menurut Allah di dalam kebenaran dan Pertama, ayat 25, $\lambda \alpha \lambda \varepsilon \tilde{\imath} \tau \varepsilon \dot{\alpha} \lambda \dot{\eta} \theta \varepsilon i \alpha v$ merupa-kan perintah untuk berkata kebenaran. Verba imperatif ini dijelaskan oleh partisip aorist $\dot{\alpha} \pi o \theta \varepsilon \dot{\mu} \mu \varepsilon v o r$. Setelah tidak lagi berdusta maka diganti dengan mengatakan kebenaran seorang kepada yang lain karena semuanya merupakan satu di dalam Kristus. Kedua, ayat 26-27, verba imperatif ó $\rho \gamma i \zeta \varepsilon \sigma \theta \varepsilon \kappa \alpha i$ $\dot{\alpha} \mu \alpha \rho \tau \dot{\alpha} v \varepsilon \tau \varepsilon \mu \grave{\eta}$ "Kamu marah tetapi jangan berbuat dosa." Jangan marah sampai berlarut-larut agar iblis tidak memakai kemarahan tersebut untuk berbuat dosa. Ketiga, ayat 28 diawali dengan verba partisip $o$ $\kappa \lambda \dot{\varepsilon} \pi \tau \omega v$ "orang yang mencuri” menunjuk orangorang yang mencuri secara terus menerus; melain-

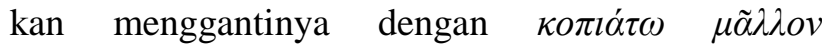

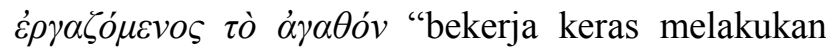
pekerjaan baik" lalu diikuti dengan frasa $\tau \alpha \tilde{\imath} \varsigma \chi \varepsilon \rho \sigma i v$

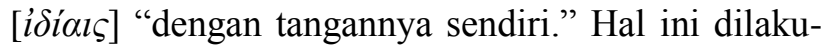
kan agar dapat berbagi sesuatu kepada orang yang berkekurangan. Jadi, alasan utama Rasul Paulus menasihatkan bahwa orang yang sudah mengenakan manusia baru untuk tidak mencuri lagi agar mereka dapat bekerja keras sehingga dapat berbagi satu dengan yang lain. Keempat, ayat 29 menasihatkan untuk tidak berkata kotor. Jangan biarkan ada perkataan kotor keluar dari mulut kamu; tetapi gunakan semua perkataan yang baik di mana perlu untuk saling membangun; supaya kasih karunia diperoleh mereka yang mendengarnya. Dalam Efesus 5:4 diartikan sebagai perkataan yang kosong dan sembrono. Perkataan seperti ini tidak boleh keluar dari mulut orang yang sudah mengenakan manusia baru; melainkan menggantinya dengan perkataan yang dapat memberkati dan membangun kehidupan orang

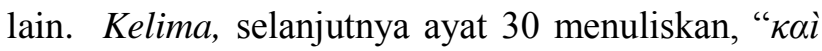

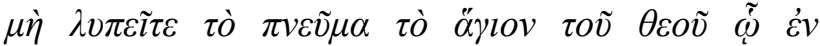

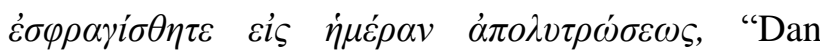
jangan mendukakan Roh Kudus Alah, yang telah memeteraikan kamu menjelang hari penyelamatan." Dalam 1 Tesalonika 5:19 tidak mendukakan Roh Kudus Allah sama artinya tidak memadamkan Roh. Artinya tidak memberontak terhadap Roh Kudus Allah di mana secara terang-terangan menolak Roh Kudus Allah bekerja dalam hidup mereka. Arti lainnya melawan Roh Kudus (Kis 7:51). Keenam,

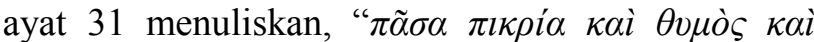

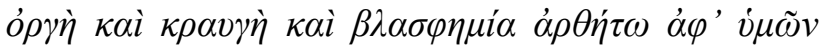

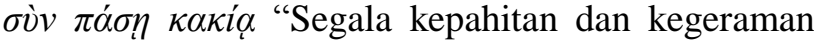
dan kemarahan dan pertikaian dan fitnah; hendaklah dibuang dari kamu dengan semua kejahatan."Verba $\dot{\alpha} \rho \theta \dot{\eta} \tau \omega$ "buanglah" merupakan perintah yang harus dilakukan dari dulu, sekarang dan di masa yang akan datang. Kepahitan, kegeraman, kemarahan, pertikaian dan fitnah harus benar-benar tidak ada di dalam hidup orang yang sudah mengenakan manusia baru. Ketujuh, selanjutnya ayat 32 dan ayat ini merupakan pengganti ayat dari 31. Jemaat harus berbuat baik seorang terhadap yang lain, penuh kasih sayang dan

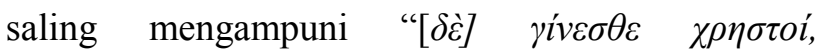

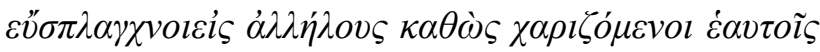

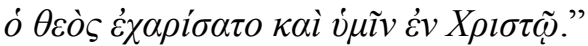




\section{Manusia Baru}

Konsep manusia baru berdasarkan surat Efesus 4:17-32 dapat dibagi tiga bagian. Manusia baru yang telah mempelajari Kristus yaitu yang mendengar Dia dan diajar di dalam Dia menghasilkan 3 hal pokok tentang manusia baru. Pertama, manusia baru adalah manusia yang telah menanggalkan manusia lama yang membawa kepada kebinasaan menurut hawa nafsu yang menyesatkan. Kedua, manusia baru adalah manusia yang telah diperbarui di dalam roh dari nous. Ketiga, manusia baru adalah manusia yang diciptakan menurut Allah di dalam kebenaran dan kekudusan yang sebenarnya yang kemudian dijelaskan dalam satu rangkaian konsekuensi di dalamnya yaitu pemurnian jiwa dan tubuh dalam wujud perbuatan-perbuatan baik dan melawan hawa nafsu.

Setiap orang yang mengenal Kristus adalah mereka yang telah mendengar tentang Dia dan menerima pengajaran tentang kebenaran yang diajarkan oleh Kristus. Mereka memiliki hidup kekal karena mereka mengenal Kristus (Yoh. 17:3). Sebab itu mereka mendapat kodrat baru supaya mereka bisa masuk dalam Kerajaan Allah menjadi makhluk cahaya seperti matahari bercahaya (Mat. 13:43). Seperti kata Rasul Paulus manusia yang mengenal Kristus telah mati dan bangkit bersama Kristus (Rm 6:3-5). Hal ini terjadi dalam roh sehingga benar roh itu dibarui yakni nous yang merupakan inti dari roh manusia (Ef 4:23). Nous yang dibarui ini membuat roh menjadi roh yang baru sehingga memiliki kodrat baru yakni manusia baru yang kembali kepada kebenaran dan kekudusan yang sesungguhnya (4:24). Kembali kepada ciptaan Allah dalam Kristus Yesus (Ef 2:10) sebagai gambar dan rupa Allah yang sempurna. Beginilah setiap orang yang mengenal Kristus adalah mereka yang memiliki hidup kekal dengan kondisi kembali kepada manusia ciptaan Allah yang baru dan yang sesungguhnya di dalam Kristus sesuai kehendak Allah (Ef 4:24).

Sebaliknya orang yang tidak mengenal Kristus adalah orang yang tidak mengenal Allah (Yoh $8: 19$; 14:7) sehingga nous mereka hidup dalam kesia-siaan (Ef 4:17) atau dalam kematian (Ef 2:1). Akibatnya pengertian atau hati manusia menjadi gelap karena tidak mengenal Allah yang adalah terang itu (1 Yoh 1:5). Pengertian yang gelap ini atau roh yang masih dalam keadaan mati ini disebabkan manusia hidup dalam dosa-dosa (Ef 2:1). Hidup dalam dosa-dosa ini disebabkan karena kebodohan yang ada di dalam mereka dan kedegilan hati mereka (Ef 4:18). Akibatnya hidup mereka adalah hidup yang penuh hawa nafsu dan kecemaran (Ef 4:19). Hidup yang demikian tentu hidup yang jauh dari Allah sehingga Rasul Paulus menyatakan orang yang demikian adalah mereka yang tidak bersekutu dengan Allah (Ef 4:18) yang merupakan tanda kematian atau kebinasaan.

\section{Manusia baru: menanggalkan manusia lama}

Saumiman Saud (2004, p.50) menyatakan bahwa sebagai orang percaya yang sudah ditebus oleh Kristus di atas kayu salib, sehingga tidak bisa hanya berubah di dalam konsep pemikiran saja, tetapi juga seluruh tingkah pola yang tercakup di dalamnya. Daya tarik manusia lama sangat kuat, seringkali ditarik begitu rupa supaya kembali ke sana lagi. Hidup orang percaya adalah perubahan terus menerus menuju sempurna; seseorang yang hidup di bawah kuasa kehidupan manusia lama dibawa menuju kepada kemerdeka-an yang dibentuk di dalam ruang lingkup manusia baru sesuai kehendak Allah.

Hendi (2017, p.56) juga menyatakan hal yang sama bahwa mereka yang telah ditebus dosanya oleh Kristus adalah mereka yang mengenal Allah (1 Yoh 2:2-3). Mengenal Allah adalah mereka yang bisa bersekutu dengan Allah dan Kristus (1 Yoh. 1:3), menjadi anak-anak Allah (1 Yoh. 3:1), dan memelihara perintah-perintah-Nya (1 Yoh. 2:3). Sehingga kehidupan di dunia adalah merefleksikan kehidupan kekal kelak. Kehidupan di dunia melalui Kristus tetap terhubung dengan Allah, tidak terputus dari Allah di dalam persekutuan dengan-Nya. Orang yang mendengar ajaran tentang Yesus maka akan menghasilkan tindakan kebenaran dalam kehidupan- 
nya. Tunner (2002, p. 23) juga menjelaskannya bahwa ketika seseorang mendengar tentang Kristus dan membiarkan pengajaran menembus hati, hasilnya adalah taat dan melakukan kebenaran. Menerima Yesus Kristus berarti mengijinkan Dia bekerja dalam kehidupan dan tetap bekerja sama dengan Yesus Kristus. Jika dulu keinginan yang hanya dikuasai oleh hawa nafsu namun sekarang dikuasai oleh pikiran atau nous Kristus (1 Kor 2:16). Sekarang kehidupan adalah kehidupan yang berada dalam Kristus dan hidup bagi Kristus di mana di dalam Kristus orang percaya berakar, dibangun, bertambah kuat dan berlimpah ucapan syukur (Kol 2:6-7). Hidup yang dihidupi manusia baru adalah Kristus yang hidup di dalamnya ( $\mathrm{Gal} 2: 20)$.

\section{Manusia baru: roh dari nous manusia diperbaharui}

Mereka yang telah mempelajari Kristus yaitu mereka yang mendengar Dia dan diajar di dalamDia mendatangkan pembaruan roh dari nous manusia sehingga roh yang dulunya mati (Ef 2:1) dihidupkan lagi atau dilahirkan baru menjadi manusia baru atau mengenakan manusia baru. Roh yang dihidupkan ini memperbarui nous manusia ( $\mathrm{Rm}$ 12:2). Inilah mengapa orang yang mengenal Kristus adalah manusia baru di dalam roh dan nous-nya. Memang secara jasmani orang percaya masih memakai tubuh yang lama (nanti ketika Kristus datang kedua kali, maka akan me-makai tubuh kemuliaan) namun batiniah adalah baru.

Menurut Antonius Agung (1984, p. 333) bahwa nous adalah penderma dan juruselamat jiwa. Nous juga dapat diartikan sebagai "mata hati manusia" atau "mata batin" atau "mata jiwa" (Hendi, 2018, p. 278). Mata hati manusia di sini diterjemahkan sebagai Hegemonikon atau Nakhoda, yaitu kapten kapal dari jiwa yaitu pemimpin dan penguasa dari pribadi seseorang. Bahkan lebih tepat seperti yang dikatakan oleh Yesus Kristus sebagai "Pelita dari tubuh manusia" (Mat 6:22-23).

Nous adalah mata batin. Mata batin ini harus memandang kepada Kristus sehingga mata batin ini menjadi terang oleh anugerah Allah. Mata batin ini ibarat seperti otak dari batin atau jiwa. Jika otak dikendalikan oleh Nous Kristus maka nous akan melahirkan keinginan Roh dan buah Roh. Jika nous dikuasai oleh godaan Iblis maka akan melahirkan nafsu daging dan perbuatan daging atau dosa.

Roh harus semakin dewasa melalui pembaruan nous atau manusia baru ( $\mathrm{Rm} \mathrm{12:2;} \mathrm{Kol} \mathrm{3:10)}$ yang dituntun oleh Roh Kudus (Gal 5:16) sehingga nous tadi dapat menjadi penjaga atau benteng pertahanan terhadap serangan Iblis atau godaan-godaan terhadap keinginan daging atau tubuh. Tubuh dengan segala macam keinginannya merupakan hasil kerja biologis yang dirancang Allah. Keinginan makan karena rasa lapar, seks, rasa aman, damai, indah, dihargai, bersosial, dan sebagainya adalah kerja tubuh dan roh. Keinginan itu adalah baik namun rentan terhadap serangan Iblis yang membuat keinginan itu menjadi nafsu atau keinginan daging (lust; EPITHUMIA) yang jika dibuahi akan melahirkan dosa (Yak 1:14-15). Tubuh atau daging itu selalu lemah sedangkan roh memang penurut (Mat 26:41) sehingga roh ini harus tumbuh semakin dewasa yang dihidupi oleh Roh Kudus (Gal 5:16). Sebab itu, Rasul Paulus menyatakan, "Hidup-lah oleh Roh, maka kamu tidak akan menuruti keinginan daging. Sebab keinginan daging berlawanan dengan keinginan Roh dan keinginan Roh berlawanan dengan keinginan daging karena keduanya bertentangan sehingga kamu setiap kali tidak melakukan apa yang kamu kehendaki. Akan tetapi jikalau kamu memberi dirimu dipimpin oleh Roh, maka kamu tidak hidup di bawah hukum Taurat" (Gal 5:16-18).

Menafsirkan kata "Nous" sebagai "akal budi" (Rm 7:26) atau "budi" (12:2), dan "pikiran" (Ef 4:23) seperti yang terdapat dalam terjemahan LAI adalah kurang tepat. "Nous" merujuk pada "mata batiniah" dari "jiwa/roh" yang melakukan pengendalian atas serbuan "logismoi" ("angan-angan/ alur-alur pemikiran/pikiran") yang mengacaukan perhatian/keterpusatan, melalui keberjaga-jagaan/ 
keterpusatan perhatian/ kesiapan waspadaan dan doa (Hendi, 2018, p.146-47).

Nous itu dirancang untuk menjadi kepala atas seseorang sebagai "hegemonikon" atau nahkoda, yaitu "kapten kapal" dari jiwa/roh, yaitu pemimpin dan penguasa dari pribadi seseorang. Namun demikian karena kejatuhan manusia "nous" telah terlukai dan sekarang tunduk kepada "EPITHUMIA" atau "Hawa Nafsu" (Gal 5:24), oleh keinginan-keinginan yang dipaksakan, oleh nafsu-nafsu yang amat berkuasa dalam diri manusia. Hanya dengan KasihKarunia/ Rahmat Allah yaitu Energi Ilahi saja yang disertai "ASKESIS" (latihan/ disiplin rohani) - 1 Korintus 9:27 - dan Mati-Raga (Kol 3:5) yaitu penyaliban kehendak dan kemauan (Gal 5:24) sajalah dapat menyembuhkan dan mampu untuk menguasai "EPITHUMIA" dan keinginan-keinginannya oleh kuasa Roh Kudus yang bekerja melalui Energi Ilahi di dalam orang percaya, yang berkarya melalui "HEGEMONIKON" yang menjadi mahkota terpuncak yang memerintah atas kerajaan diri manusia (Hendi, 2018, p.147).

Nous yang dibaharui ini membuat Roh manusia menjadi Roh yang baru sehingga memiliki kodrat baru di dalam Kristus. Itu sebabnya tanpa memperbarui Nous atau pikiran mempunyai peluang yang sangat besar bagi kejahatan (Oliver R. Barclay, 1993, p.9). Tidak mengarahkan nous kepada Kristus mempunyai kehidupan yang terpisah dari Allah (Martin Kitchen, 1994, p. 85). Mereka ini mempunyai kehidupan yang tidak mengenal Allah yang membuat nous mereka hidup dalam kesia-siaan (Ef 4:17) atau dalam kematian (Ef 2:1).

Nous yang berada dalam kesia-siaan membawa kepada kehidupan yang gelap yang tidak mengenal terang yaitu Kristus sendiri. Orang yang tidak hidup dalam Kristus maka hidupnya seperti orang buta yang meraba-raba dan tanpa tujuan yang jelas. Jakes (2012, p.32) menyatakan bahwa mengabaikan hal-hal rohani berarti hidup dalam kegelapan, yang tidak menghasilkan apa-apa selain merabaraba, menggenggam, dan tanpa tujuan. Orang yang berjalan dalam kegelapan adalah orang yang tidak tahu ke mana ia akan pergi atau apa yang akan ia kunjungi. Orang seperti itu cenderung dipenuhi dengan frustrasi, kebingungan, dan ketakutan. F.F. Bruce (2012, p.132) menyatakan hidup yang seperti ini ialah hidup yang secara batiniah sudah mati, keterasingan umat manusia dari Allah melibatkan keadaan kematian spritual, karena Allah yang adalah dirinya sendiri kehidupan, adalah satu-satunya sumber kehidupan bagi semua manusia.

Itu sebabnya nous haruslah diperbaharui agar kehidupan orang percaya juga menjadi kehidupan yang terang; tidak lagi berada dalam kegelapan. Dengan tepat dapat dikatakan bahwa Nous inilah yang menentukan gelap atau terang kehidupan. Anthony Coniaris(1998, p. 112) menuliskan bahwa berjaga-jaga berarti bahwa ketika berdoa seluruh manusia berdiri di hadapan Allah dengan perhatian penuh. Orang percaya sepenuhnya hadir untuk Allah ketika berdoa kepada-Nya. Pikiran (nous) tidak seperti TV rusak yang tidak dapat dimatikan, atau beralih saluran, atau menurunkan volume. Pikiran bisa dikendalikan. Pikiran (nous) memiliki saklar kendali (hegemonikon) yang mengendalikan pikiran-pikiran (logismoi). Hegemonikon (intelek atau nous) adalah juru mudi jiwa. Tanpa juru mudi, sebuah kapal tidak akan pernah mencapai pelabuhan. Secara khusus, hegemonikon adalah "pikiran Kristus" dalam baptisan kudus. Intelek (nous) adalah "mata jiwa" sebagaimana Yesus berkata, "Jika karena itu, matamu tunggal, seluruh tubuhmu akan penuh dengan cahaya. Tetapi jika matamu jahat; seluruh tubuhmu akan penuh dengan kegelapan" (Mat 8: 22-23). Pikiran-pikiran jahat dikerumuni oleh intelek (nous) melalui pengamatan, doa, khususnya Doa Puja Yesus, membaca Mazmur, dan Kitab Suci pada umumnya. Ketika seseorang bertanya kepada seorang biarawan di gunung Athos, "Apa yang kamu lakukan di sini sepanjang waktu?" Biarawan itu menjawab, "Kami terus menjaga pikiran (nous) dengan berjaga-jaga."

Nous yang diperbarui di dalam Kristus berarti nous yang dikontrol oleh Nous Kristus. Nous yang dikuasai/dikontrol Nous Kristus sama artinya 
orang percaya memiliki pikiran Kristus. Apa yang Kristus pikirkan itu juga yang orang percaya pikerkan. Pembaruan Nous adalah esensial di dalam latihan jiwani. Nous adalah mata batin yang berfungsi untuk melihat Kristus, berjumpa dengan Kristus, dan menerima Nous Kristus melalui Roh Kudus. Tanpa ada pembaruan nous ini maka latihan badani tidak akan berjalan sehingga manusia lahiriah tidak diperbarui atau terus di dalam dosa. Sebab itu Yesus mengajarkan, "Matamu adalah pelita tubuhmu. Jika matamu baik, teranglah seluruh tubuhmu, tetapi jika matamu jahat, gelaplah tubuhmu" (Luk 11:34). Mata di sini adalah mata spiritual seseorang, yaitu mata batin yang disebut nous itu. Nous yang baik akan menghasilkan perbuatan tubuh yang terang dan sebaliknya nous yang jahat akan menghasilkan perbuatan yang gelapatau dosa. Jadi, terang gelapnya perbuatan atau hidup ditentukan dari dalam batin atau jiwa yaitu nous itu.

Manusia baru: manusia yang diciptakan menurut Allah di dalam kebenaran dan kekudusan yang sebenarnya. Manusia yang merupakan gambar Allah memiliki roh (spirit; pneuma) dan jiwa (soul; psyche) sebagai satu kesatuan, dan tubuh (soma). Soul manusia yang berasal dari napas atau Roh Allah sifatnya seperti Allah Trinitas, yaitu memiliki Nous (seperti Allah Bapa), Logos (seperti Firman Allah), dan Pneuma (seperti Roh Allah). Logos adalah manifestasi dari Nous. Logos adalah reason atau pikiran manusia yang bekerja memerintah otak dan dari otak memerintah anggota tubuh manusia. Seluruh perangkat batin ini tertampung didalam suatu wadah yang sebut sebagai hati (kardia). Di dalam hati atau perangkat batin ini tersimpan berbagai memori manusia yang tertampung di dalam logos manusia. Hati ini ibarat lemari batin (the inner closet) manusia yang di dalam terdapat dua kekuatan besar (Rm 7:21-23) yaitu hukum Allah (seperti superego dalam teori psiko analisis Sigmund Freud) dan hukum dosa (id) yang berasal dari tubuh atau daging. Tubuh ini memiliki keinginan atau kebutuhannya seperti makan, seks, pakaian, materi, atau uang untuk melindungi tubuh, istirahat, refreshing, dan sebagainya. Keinginan tubuh atau daging ini sebetulnya normal atau baik karena memang dirancang oleh Allah demikian. Namun, karena semua manusia telah jatuh dalam dosa (Rm 3:23) sehingga keinginan daging ini melanggar hukum Allah (1 Yoh 3:4) seperti keinginan makan menjadi distorsi dalam wujud gluttony atau keserakahan akan makanan. Perbuatan dosa ini berasal dari keinginan daging dan dosa ini tersimpan menjadi sebuah id yang tersimpan di dalam lemari batin. Sementara itu, didalam setiap hati manusia tertulis hukum Allah walaupun dia tidak mempelajari hukum itu seperti Hukum Taurat (Rm 2:1416) maupun dia mempelajari hukum itu. Hukum Allah ini tersimpan di lemari batin setiap manusia. Jadi, memang di dalam perangkat batin orang percaya ada hukum Allah yang tertulis di dalam hati (superego) dan sekaligus ada hukum dosa atau id yang tersimpan rapi didalam hati seperti dosa glutony tadi. Perangkat batin atau hati dilindungi oleh Nous sebagai egemonikon atau shield atau pertahanan dari jiwa. Nous yang sia-sia yang terpisah dari Allah dan mati ini (Ef 4:17-18; 2:1) ini harus dihidupkan lagi oleh anugerah Allah atau energi Ilahi, yakni penebusan Kristus (Ef 2:4-5) sehingga roh (spirit) dari Nous ini dibarui dan mengenakan manusia baru yang sesuai kodrat aslinya (Ef 4:23-24). Manusia baru ini berarti nous ini bisa kembali berhubungan dengan Allah. Nous ini harus mengenakan pikiran Kristus sebab Kristus yang telah menghidupkan nous ini dari kesia-siaan dan kematian.

Iblis dan godaannya seperti singa mengaumaum yang senantiasa mencari orang yang dapat ditelannya (1 Ptr 5:8). Iblis selalu menggoda titik lemah manusia, yaitu daging dan segala keinginan atau nafsunya sehingga Rasul Paulus menasihatkan orang percaya untuk menyalibkan keinginan daging (Gal 5:24) dan memang manusia dicobai oleh keinginannya sendiri (Yak 1:14). Ketika nous atau egemonikon orang percaya lemah maka godaan iblis akan masuk menguasai lemari batin seperti yang dialami Ananias dan Safira (Kis5:3). Iblis akan meng- 
uasai dan mengambil $i d$, yaitu memori di dalam lemari batin. Evagrius (1984, p.38) menjelaskan ada 7 id yang menguasai yaitu glutony, fornication,love of money, depression (lype), anger, listlessness (akedia), dan pride. Oleh John Cassian (1984, p. 73) ini disebut sebagai tujuh dosa maut. Dan ini adalah hukum dosa yang membelenggu orang percaya ( $\mathrm{Rm}$ 7:23). Yesus menjelaskan bahwa dari dalam hati timbul segala pikiran jahat (Mrk 7:21). Pikiran jahat ini adalah logismoi yang timbul dari lemari batin yang sudah dikuasai oleh iblis yang wujudnya dalam bentuk 7 id tadi. Logismoi ini merupakan benih dari passions dan desires atau nafsu atau keinginan daging yang menyeret dan memikat orang percaya sehingga ditawan olehnya dan apabila keinginan daging itu dibuahi maka akan melahirkan dosa dan dosa yang sudah matang akan melahirkan maut atau kematian (Yak 1:14-15).

Proses lahirnya dosa dan maut: Godaan iblis $\rightarrow$ Nous $\rightarrow$ Lemari batin $\rightarrow$ Id $\rightarrow$ Logismoi $\rightarrow$ Keinginan daging/nafsu $\rightarrow$ menyeret dan memikat $\rightarrow$ Dosa $\rightarrow$ Maut.

Doa $=$ Pemurnian nous, logos, pneuma, dan tubuh. Rasul Paulus menasihati untuk tidak menjadi serupa dengan dunia ini dan berubah oleh pembaruan Nous (Rm 12:2). Nous atau hukum akal budi ini harus berubah dengan pembaruan terus menerus dengan cara berdoa, berjaga-jaga, dan askesis supaya memiliki pikiran Kristus (1 Kor 2:16; Gal 2:20). Nous ini tidak boleh mengasihi dunia dan apa yang ada di dalamnya, yaitu keinginan daging, mata, dan kesombongan (1Yoh 2:15-17). Nous dan perangkat batin harus berhubungan dengan Allah. Rasul Yohanes menjelaskan bahwa di luar Kristus,orang percaya tidak dapat berbuat apa-apa (Yoh 15:5). Nous dan hati harus menjumpai Allah di dalam doa dan berjaga-jaga (nepsis). Dengan cara demikian orang percaya dapat melindungi lemari batin dikuasai oleh iblis dan godaannya.

Pemurnian batin dan jiwa: Allah $\rightarrow$ energi ilahi/anugerah Allah yang dibawa oleh Roh Kudus >Nous $\rightarrow>$ lemari batin $\rightarrow$ menjadi Superego (hukum Allah) $\rightarrow$ Logos (reason, emotion, desire) yang dikuasai Kristus - mampu approve kehendak Allah $\rightarrow$ apatheia (ketiadaan nafsu) dan melahirkan keinginan Roh $\rightarrow$ otak $\rightarrow$ anggota-anggota tubuh (penyaliban daging dan nafsu) $\rightarrow$ ketaatan dalam bentuk kasih.

Pikiran dan perbuatan Kristus $\rightarrow$ Roh Kudus $\rightarrow$ Nous $\rightarrow$ lemari batin $\rightarrow$ Logos (reason, emotion, desire) $\rightarrow$ kehendak Allah $\rightarrow$ Keinginan Roh $\rightarrow$ buah Roh (kasih).

Doa adalah sinergi manusia dengan Allah untuk menjemput energi ilahi atau terang ilahi masuk ke dalam lemari batin atau hati sehingga energi Allah itu bisa menerangi hati. Hati yang telah diterangi oleh Allah ini membuat perangkat logos atau pikiran, perasaan, dan keinginan orang percaya adalah seturut dengan pikiran Kristus atau kehendak

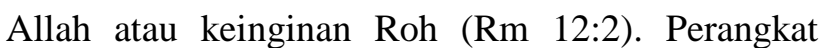
logos ini akan memerintahkan otak supaya anggota tubuh dipakai untuk melakukan kebenaran atau menghasilkan buah Roh. Jadi, doa itu adalah sinergi manusia dengan Allah untuk menjemput energi ilahi untuk memurnikan hati, batin dan daging.

Palamas (1984, p. 332) sangat menekan-kan tentang doa, karena doa adalah persekutuan dengan Tuhan (nous dan pneuma) berelasi dengan Tuhan secara pribadi dan dekat. Tidak hanya hubungan saja tapi harus dekat, selain itu menyadari dengan sungguh kehadiran Allah. Bukan hanya sekedar hubungan satu arah tapi lebih dari sekedar kata-kata dan pikiran (doa spontan dengan kata-kata). Gregory mengatakan dalam doa roh orang percaya bersatu dengan Allah untuk menyerap energi Allah.

Orang percaya berdoa dan memandang kepada Allah sebagai pemilik kehidupan. Bukan memandang kepada keinginan daging. Karena itu Yesus berkata "carilah dahulu kerajaan Allah ... maka semuanya akan ditambahkan Allah." (Mat 6:33) Maksudnya pikiran orang percaya terkoneksi dengan Allah supaya nous membawa energi ilahi tanpa henti. Sederhana doa adalah menjemput energi ilahi Allah untuk masuk ke dalam nous. Rasul Petrus menulis dalam 1 Petrus 1:13, "Siapkanlah akal budimu!" Bagaimana mungkin nous ini menyerap energi 
ilahi Allah? Orang percaya harus tahu bahwa ada kerja roh, sehingga doa itu harus menjemput energi ilahi Allah. Sehingga doa itu perlu dikerjakan karena itu perlu doa tanpa henti (unceasing prayer). Bagaimana caranya doa 24 jam tanpa henti? Itulah yang disebut doa batin, di mana roh tidak pernah tidur, jadi bukan lewat mulut. Maka apa hasilnya? Purify our soul, jemput energi Allah untuk memurnikan jiwa agar nafsu daging atau passion disingkirkan dan ini bersifat misteri. Doa itu masuk ke dalam sukma, jiwa atau lubuk hati untuk memurnikan daging sehingga mengalami dispassion dan melakukan kebenaran. Ini menunjukkan bahwa lemari batin orang percaya tidak bisa diukur betapa dalamnya.

\section{Satu rangkaian pemurnian jiwa dan tubuh}

Roh dari nous manusia diperbaharui, mendengar, diajar dan menerima Yesus Kristus merupakan proses dalam pemurnian roh dan jiwa manusia. Setelah roh dan jiwa manusia diperbaharui; tubuh juga perlu untuk diperbaharui sebab di dalam diri manusia masih ada manusia duniawi yang keinginananya selalu berorientasi kepada kejahatan. Orang percaya perlu menyalibkan kedagingan.

\section{Membuang dusta}

Membuang dusta diantara orang percaya merupakan hasil atau ciri orang yang sudah menjadi manusia baru. Efesus 4:25 menuliskan, "Karena itu buanglah dusta.... seorang kepada yang lain.” Dusta merupakan sifat manusia lama (Abineno, 1993, p. 158). Membuang dusta di-antara orang percaya adalah suatu keharusan. Alasan utamanya karena melalui dusta bisa mendikte kehidupan dan akan cenderung menyimpang dari kebenaran.

Oleh sebab itu, dusta harus disingkirkan agar pengertian dan pikiran selaras dengan pengertian dan pikiran Kristus yang berimplikasi kepada berkata yang benar seorang kepada yang lainnya. Kenapa? Karena semuanya adalah sesama anggota tubuh Kristus. Sesama anggota tubuh Kristus berarti ada persekutuan kasih. Di dalam persekutuan ter- sebut ada tindakan aktif di mana sesama anggota saling melayani dan bertanggungjawab satu sama lain. Karena itu dusta harus disingkirkan dalam persekutuan, sebab ketika ada dusta/ketidakjujuran maka akan membuat persekutuan tersebut hancur dan merusak hubungan sesama anggota tubuh Kristus. Seperti yang dituliskan Stott (2002, p. 179) bahwa pendusta merongrong persekutuan, tapi orang yang berkata benar mengukuhkan persekutuan. Dusta hanya akan membawa relasi menjadi hancur dan tidak bisa menjadi berkat bagi masyarakat luas.

\section{Tidak marah sampai berlarut-larut}

Hal ini bukanlah pernyataan bahwa orang Kristen tidak boleh marah. Kemarahan merupakan sifat dasar manusia sehingga semua orang bisa marah dan pernah marah. Stephen Tong menuliskan, "Siapa orang yang tidak bisa marah? Seorang anak yang masih sangat kecil pun bisa marah. Orang yang tidak belajar apa-apa juga bisa marah. Marah bukan sesuatu yang memerlukan keahlian atau kemampuan khusus untuk melakukannya. Setiap orang bisa marah. Marah adalah suatu naluri atau insting atau pembawaan yang bersifat alamiah (natural). Kemarahan adalah sifat yang begitu mendasar, yang terkadang begitu cepat untuk dilakukan (Tong, 2011, p. 75). Bahkan ada kemarahan yang kristiani yakni marah akan dosa-dosa. Kemarahan ini ialah kemarahan yang benar (Barclay, 2004, p.232).

Terus kemarahan apa yang dimaksud di sini? Kemarahan yang membuat orang percaya berdosa. Kemarahan yang tidak dikontrol dengan segera dimana kemarahannya itu dibiarkan sampai keesokan harinya. Kenapa tidak boleh menyimpannya sampai keesokan harinya? Karena kemarahan yang seperti ini akan membawa kepada kecongkakan, kebencian, kedengkian, perseteruan dan keinginan balas dendam (Stott, 2002, p. 180). Ketika balas dendam muncul maka pengampunan akan sulit dijalankan sehingga merusak keharmonisan dalam persekutuan (Ndhlovi, 2013, p.58). 
Pencuri tidak mencuri lagi

Mencuri adalah kebiasaan hidup lama. Sekarang jemaat sudah mengenakan manusia baru di dalam hidup orang percaya. Oleh karena itu, kebiasaan lama ini harus dibuang jauh-jauh dan menggantinya dengan kehidupan yang baru seperti bekerja keras dengan tangannya sendiri. Siapa yang mencuri? Dalam konteks ini, rasul Paulus menuliskannya untuk konteks umum; kepada semua orang. Mencuri seperti apa dimaksud? Mencuri bisa berarti mengambil uang atau benda milik orang lain, menggelembungkan harga proyek, mengelak membayar pajak, mengurangi atau membayar tidak layak gaji karyawan, pembantu atau tenaga lepas, buruh yang malas bekerja ..." (Stott, 2002, p.181).

Tetapi tidak berhenti larangan untuk tidak mencuri. Setelah berhenti mencuri rasul Paulus menasihatkan agar bekerja keras dengan tangannya sendiri di mana melaluinya tidak hanya memberkati diri sendiri melainkan dapat memberkati orang lain. Stott menuliskan, Tapi sesudah mengutip titik kedelapan itu, Paulus maju selangkah lagi dengan anjuran siapa berbuat. Jadi, tidak cukup hanya berhenti mencuri. Sang petobat harus bekerja sehingga dapat membiayai dirinya dan keluarga, bahkan memberi persembahan dan diakonia (Stott, 2002, 181). Jadi, berhenti mencuri dan bekerja keras agar dapat memberkati diri sendiri dan juga orang lain.

Selain itu bekerja keras dengan tangan-nya sendiri dan dapat memberkati orang lain merupakan komunikasi yang baik terhadap sesama. Dengan bekerja keras dan membantu orang lain, orang percaya sedang secara tidak langsung memberitakan Kristus. Tidak ada kata-kata yang keluar dari mulut tetapi tindakan yang langsung dilihat oleh orang lain lebih konkrit daripada hanya sekedar teori saja.

\section{Tidak memperkatakan perkataan kotor}

Allah membuat mulut dalam diri manusia berguna untuk berbicara. Berbicara dengan mulut merupakan karunia Allah dalam diri manusia. Alasannya karena Allah menciptakan manusia sama seperti diri-Nya yang dapat berbicara. Karunia ini berbeda dengan yang didapat oleh ciptaan Allah lainnya seperti binatang dan tumbuhan yang tidak dapat berbicara.

Jika mulut merupakan karunia dari Allah maka sebagai orang yang sudah mengenakan manusia baru hendaknya memakai mulut kearah yang positif. Hal yang didengungkan oleh rasul Paulus ialah tidak memperkatakan kata-kata kotor melalui mulut. Biarlah melalui mulut orang percaya mencerminkan karya Kristus melalui cara hidup. Jangan biarkan perkataan jahat keluar dari mulut. Karena bicara jahat hanya akan menyakiti pendengar yang ada di sekitar. Lebih daripada itu, orang yang mengenakan manusia baru berarti hidupnya adalah hidup yang baik (Mark. J. Edwards, 1999, p.184). Kata-kata kotor yang keluar dari mulut seseorang tidak membuktikan dirinya sudah mengenakan manusia baru dalam hidupnya.

Hendaklah dengan mulut yang merupakan karunia Tuhan haruslah mulut yang membangun kehidupan orang lain. Perkataan seperti apa yang dapat membangun kehidupan orang lain? Ialah perkataan yang senantiasa memperkatakan Firman Allah. Hendaknya dengan mulut orang percaya menerima berkat bukan kutuk. Hal ini sangat penting sekali untuk diperhatikan. Kenapa? Karena dengan mulut yang sama bisa saja keluar berkat tetapi bisa juga kutuk yang keluar. Dengan mulut yang sama bisa mengeluarkan kata-kata yang sesuai dengan perkataan Yesus Kristus tetapi bisa juga mengeluarkan kata-kata yang tidak sesuai dengan perkataan Yesus Kristus bahkan melawan apa yang diajarkan Yesus Kristus. Stott memberi komentarnya dengan mengutip perkataan Yesus Kristus, "Yesus juga mengajar perihal pentingnya perkataan. Kata-kata menyatakan isi hati, dan setiap kata sia-sia yang diucapkan orang harus dipertanggung-jawabkannya pada hari penghakiman (Mat 12:36). Rasul Yakobus meng-ulangi ajaran Yesus, ketika ia menekankan betapa besarnya kuasa lidah untuk membuat yang baik atau jahat (Yak 3:1-12) (Stott, 2002, p.182). 


\section{Tidak mendukakan Roh Kudus Allah}

Semua hal yang berhubungan hal jahat dihadapan Allah merupakan hal yang membuat Roh Kudus berduka. Roh Kudus adalah kudus dan juga berkepribadian maka semua hal yang tidak kudus pasti mendukakan. Mendukakan Roh Kudus dalah tindakan yang tidak menghormati Dia. Mendukakan Roh Kudus Allah berarti kata yang arogan mendukakan Roh Kudus (Edwards, 1999, p.185). Hal yang sama diperjelas oleh Edwards mengutip Ambrosiaster bahwa Roh Kudus bersukacita karena keselamatan orang percaya bukan untuk dirinya sendiri, karena Roh Kudus tidak memiliki kekurangan berkat. Jika orang percaya tidak mematuhi Roh, telah mendukakan Roh. Pekerjaannya di dalam diri terpotong, tepat ketika dia ingin menjadi bagian dari kehidupan (Edwards, 1999, p.185).Roh Kudus yang bekerja dan bersukacita dalam keselamatan akan berduka jika tidak taat kepada-Nya. Hal ini akan menyebabkan Dia akan berhenti bekerja di dalam diri orang percaya.

Namun yang menjadi pertanyaan sekarang ialah mengapa Rasul Paulus langsung mengalihkan nasihatnya dari menggunakan perkataan yang benar kepada jangan mendukakan Roh Kudus? Jawaban yang cukup jelas diterangkan oleh Bruce. Bruce (2012, p.163) menuliskan bahwa percakapan yang membantu membangun kehidupan bersama di dalam Kristus adalah alat yang cocok untuk Roh Kudus gunakan untuk tujuan ini. Di sisi lain, percakapan (atau kegiatan lain apa pun) yang membahayakan kesatuan tubuh Kristus "mendukakan" Roh Kudus. Melalui percakapan yang kotor menjadi-kan Roh Kudus berduka karena akan membahayakan persatuan tubuh Kristus.

\section{Membuang Segala Kepahitan, kegeraman,}

\section{Kemarahan, Pertikaian dan Fitnah}

Kepahitan, kegeraman, kemarahan, pertikaian dan fitnah merupakan golongan kejahatan. Semuanya ini harus dibuang total. Mengapa harus dibuang? Selain tidak mencerminkan kehidupan orang yang sudah mengenakan manusia baru; melalukan lima hal ini juga sama artinya dengan mendukakan Roh Kudus (Bruce, 2012, p.164) karena sifat kehidupan yang seperti itu bertentangan dengan sifat kudus-Nya dan kehendak-Nya.

Kepahitan apa yang dimaksud di sini? Kepahitan (pikria) berarti roh masam dan pembicaraan masam, yang mendendam dan menolak didamaikan. Ada perasaan tidak mau lagi hidup damai dengan orang lain. Tidak lagi memberi pengampunan kepada orang yang bersalah kepadanya. Tetapi meminta pengampunan kepada orang lain bahkan kepada Tuhan sangat gampang untuk diucapkan. Berharap agar Tuhan mengampuni kesalahan kita dan tidak berlaku dengan dirinya untuk mengampuni orang lain (Jonar Situmorang, 2015, p.104). Jika hal ini terjadi di mana diri orang percaya tidak membuka hati untuk mengampuni orang lain maka akan cenderung berpikiran negatif terhadap orang lain sehingga menimbul-kan reaksi iri dan berbicara buruk terhadap orang lain. Sifat yang seperti ini akan membawa keretakan hubungan baik dalam rumah, gereja dan juga dalam pertemanan. Itu sebabnya kepahitan tidak boleh ada (harus dibuang bukan dijauhi) dalam kehidupan orang sudah mengenakan manusia baru. Bahkan Barclay (2004, p.238) menawarkan solusi agar orang percaya sebagai orang yang sudah mengenakan manusia baru berdoa dan meminta tuntunan Allah agar dapat melupakan semua itu.

Kegeraman (Thymos) dan kemarahan (Orge) hampir sama artinya atau kedua-duanya saling berhubungan. Kegeraman itu menekankan ledakan dan kemarahan menekankan sifat yang terus menerus berseteru. Kegeraman dan kemarahan ibarat pikiran yang sudah mendidih sehingga menimbulkan reaksi yang tidak masuk akal di hadapan manusia. Jerome menuliskan bahwa kegeraman yang pada akhirnya menimbulkan amarah itu sama artinya dengan murka (Edwards, 1999, p. 184). Murka ialah kemarahan yang menginginkan pembalasan. Murka ialah ingin sekali menyakiti orang lain bahkan orang yang terdekat sekalipun. Dua hal ini yakni kegeraman dan 
kemarahan yang berkepanjangan sama sekali tidak dibenarkan dalam kekristenan.

Pertikaian (Krauge) melukiskan orang yang bila berkelahi naik pitam dan berteriak-teriak. Orang yang sedang bertikai ialah orang yang mengucapkan kata-kata yang tak terkendali atau bisa juga disebut perkataan gila di mana bisa saja salah dan menimbulkan dosa. Dan yang terakhir adalah fitnah (Blasphemia) berarti secara tersembunyi berbicara jahat terhadap seorang sehingga nama baik orang itu tercoreng atau menghancurkan reputasi. Hidup berbuat baik untuk orang lain, penuh kasih sayang dan saling mengampuni.

Sebagai ganti kelima hal yang di atas (kepahitan, kegeraman, kemarahan, pertikaian dan fitnah) harus diganti dengan sikap yang dapat membuahkan hasil yang baik ditengah-tengah masyarakat atau jemaat. Menggantinya dengan sifat yang khas mencirikan perilaku Allah dan Kristus. Perilaku seperti apa yang cocok dengan ciri Kristus di sini? Hidup berbuat baik terhadap orang lain yang diartikan Stott hidup ramah terhadap orang lain (Stott, 2002, p.184). Hendaklah orang percaya ramah seorang terhadap yang lain dan mempunyai hati yang lembut kepada orang lain.

Selain ramah terhadap seorang kepada yang lain; orang percaya juga harus penuh kasih sayang terhadap satu dengan yang lainnya. Mengenakan manusia baru sangat jelas tidak jauh dari kehidupan Yesus Kristus. Artinya Kristus sendiri yang menjadi panutan/teladan. Yesus Kristus menunjukkan kasihNya dengan menyerahkan diri-Nya sendiri untuk orang percaya. Kristus menyerahkan diri-Nya kepada orang percaya sama artinya menyerahkan diriNya kepada orang percaya (Stott, 2002, p.184). orang percaya juga harus menunjukkan kasih kepada orang lain.

Orang yang mengenakan manusia baru juga harus dapat memberi pengampunan kepada orang lain. Mengampuni atau memberi maaf kepada orang lain adalah sifat yang menghargai atau mempraktekkan teladan Kristus yang juga mengampuni manusia yang berdosa. Orang percaya sedang me- redam balas dendam yang berkelanjutan jika berani memberi pengampunan kepada orang yang bersalah. Alasannya bukanlah karena orang tersebut layak mendapatkannya; melainkan selain dia dapat mendapatkannya juga sebagai orang yang sudah mengenakan manusia baru harus bisa memberi pengampunan kepada orang lain.

\section{KESIMPULAN}

Manusia baru di dalam penjelasan Rasul Paulus di atas dapat disimpulkan bahwa mereka yang telah mempelajari Kristus yaitu mereka yang mendengar Dia dan diajar di dalamDia menghasilkan 3 hal pokok tentang manusia baru. Pertama, manusia baru adalah mereka yang telah menanggalkan manusia lama yang membawa kepada kebinasaan menurut hawa nafsu yang menyesatkan. Kedua, manusia baru adalah manusia yang telah diperbarui di dalam roh dari nous.Ketiga, manusia baru adalah manusia yang diciptakan menurut Allah di dalam kebenaran dan kekudusan yang sebenarnya yang kemudian dijelaskan dalam satu rangkaian konsekuensi di dalamnya yaitu pemurnian jiwa dan tubuh dalam wujud perbuatan-perbuatan baik dan melawan hawa nafsu seperti membuang dusta diantara orang percaya; tidak marah sampai berlarut-larut; tidak mencuri lagi; tidak memperkatakan perkataan kotor; tidak mendukakan Roh Kudus Allah; membuang segala kepahitan, kegeraman, kemarahan, pertikaian dan fitnah; hidup berbuat baik terhadap orang lain, penuh kasih saying dan saling mengampuni.

Sebagai praksis bagi gereja maka pemurnian jiwa dan tubuh di atas dikerjakan dalam bentuk latihan jiwani dan latihan badani. Latihan jiwani menghasilkan pikiran Kristus. Latihan badani menghasilkan perbuatan-perbuatan Kristus. Latihan jiwani harus dijalani dengan hidup dalam Kristus sehingga orang percaya memiliki Pikiran (Nous) Kristus (1 Kor 2:6). Hanya Roh Kudus yang mengetahui Pikiran Kristus (Yoh 14:26; 1 Kor 2:11). Roh Kudus yang membawa Pikiran Kristus ke dalam hati manusia melalui Nous yang berinteraksi dengan Roh Kudus dalam doa, puasa, berjaga-jaga (Nepsis), sa- 
kramen, membaca Kitab Suci dan Bapa-bapa Gereja, dan sembahyang serta ibadah. Hidup yang bijaksana adalah hidup yang menjemput Pikiran Kristus dalam doa masuk ke dalam hati sehingga menguasai perangkat batin yaitu pikiran, perasaan, dan kehendak yang kemudian akan menghasilkan perbuatan Kristus dalam ketaatan. Namun, Iblis tidak tinggal diam untuk menggagalkan kehidupan orang percaya. Sebab itu, berjaga-jaga adalah langkah kedua setelah doa. Membentengi Nous dari godaan Iblis. Benteng orang percaya tidak akan kuat jika hanya mengandalkan komitmen saja. Orang percaya perlu bersinergi dengan Roh Kudus dalam bentuk puasa dan ikut sakramen Perjamuan Kudus dalam ibadah serta sembahyang secara teratur dan membaca Kitab Suci. Sinergi seperti ini akan terus meningkatkan keberjagaan. Jika orang percaya gagal jangan menyerah segera bangkit dalam bentuk pertobatan dan air mata. Pertobatan dan air mata menguduskan kembali hati untuk mulai berdoa, berjaga-jaga, dan bersinergi. Itulah siklus askesis atau latihan jiwani orang yang

\section{DAFTAR RUJUKAN}

Abineno, JL. Ch. Tafsiran Alkitab Surat Efesus. Malang: Gandum Mas, 1993.

Barclay, Oliver R. Akal Budi Kristiani: Bukan Hanya Soal Intelek. Malang: Gandum Mas, 1993.

Barclay, William, Pemahaman Alkitab Setiap Hari: Surat-surat Galatia dan Efesus,Terj. S. Wismoady Wahono. Jakarta: BPK Gunung Mulia, 2004.

Bratcher, Robert G dan Eugene A. Nida, Ephesians A Translator's Handbook on Paul's Letter to The Ephesians. New York: United Bible Societies, 1982.

Bruce, F.F. A New Presentation of His Classic the Epistle to the Ephesians. Bath, UK: Creative Communications Ltd, 2012. Anthony M. Coniaris, The Philokalia: The Bible of Orthodoz Sprituality. Minneapolis: Light and Life Publishing, 1998.

Edwards, Mark J. Ancient Christian Commentary on Scripture: Galatians, Ephesians, Philip- berjuang memperbarui Nous ( $\mathrm{Rm}$ 12:2) sampai mencapai kedewasaan penuh seperti Kristus (Ef 4:13-15). Berjuang bersama Roh Kudus supaya memiliki Nous Kristus dan akhirnya berbuah Perbuatan Kristus (buah Roh) setiap hari.

Latihan badani pada intinya adalah menyerahkan segenap anggota tubuh untuk melakukan kebenaran. Nous Kristus memimpin tubuh sehingga dengan anggota-anggota tubuh melakukan perbuatan Kristus. Rasul Petrus menasihati bahwa iman kepada Kristus harus ditambahkan kebajikan, pengetahuan, penguasaan diri, ketekunan, kesalehan, dan kasih (2 Pet 1:5-8). Iman harus mendatangkan perbuatan-perbuatan baik (virtues) atau perbuan Kristus yang puncaknya adalah kasih (Kol 3:14). Iman dan perbuatan-perbuatan adalah satu kesatuan dan ditegaskan Rasul Yakobus bahwa iman yang hidup adalah iman yang mengeluarkan atau memiliki perbuatan-perbuatan baik (Yak 2:17).

pians, Vol. VIII. Illinois: Inter Varsity Press Downers Grove, 1999.

Darius \& Robi Panggara. "Konsep Manusia Baru Berdasarkan Perspektif Paulus Dalam Efesus 4:17-32 Dan Implementasinya Dalam Kehidupan Orang Percaya." Jurnal Jaffray Vol 11, No. 2: 2013.

Evans, Tony. Kembali Kepada Kasih Mula-mula, Terj. Robert Benedictus. Jakarta: Immanuel, 1996.

Hendi. Inspirasi Batin. Yogyakarta: Lumela, 2017. .Inspirasi Kalbu. Yoyakarta: Leutiko Prio, 2017.

. Formasi Rohani: Fondasi, Purifikasi, dan Deifikasi. Yoyakarta: Leutiko Prio, 2018. Analisis Teks dan Narasi Dalam Perjanjian Baru.Yoyakarta: Leutiko Prio, 2014.

Jakes, T.D. Six Pillars from Ephesians: Life Overlowing The Spritual Walk Of The Believer. Washington, DC.: Bethany House, 2012

Keating, Corey, Exegesis of Ephesians 3:14-19 (California: Fuller Theological Seminary, 
2003), $\quad 4 ; \quad$ tersedia $\quad$ di http://www.ntgreek.org/SeminaryPapers/Exe getical\%20Paper\%20on\%20Ephesians $\% 203$ _14-19.pdf.

Kitchen, Martin. Ephesians: New Testament Readings. London and New York: Roudledge, 1994.

Martin, Ralph P. Wo Word Biblical Commentary Ephesians, Vol. 42; Ed. Bruce M. Metzger, David A. Hubbard dan Glenn W. Barker. Dallas, TexasWord Book Publisher, 1990.

Ndhlovi, John. Bible Study The Book of Ephesians. South Africa: Cosmo Baptist Church, 2013.

Saud, Saumiman. Dinamika Kehidupan Orang Percaya. Jakarta: Yayasan Sinar Nusantara, 2004.

Tong, Stephen. Pengudusan Emosi. Surabaya: Penerbit Momentum, 2011.

Situmorang, Jonar. Doa Bapa Kami: Bukan Sekadar Doa Liturgi. Yogyakarta: Andi Offset, 2015.

Stott, John R.W. Seri Pemahaman dan Penerapan Amanat Alkitab Masa Kini: Efesus. Terj. Martin B. Dainton dan H.A. Oppusunggu. Jakarta: Yayasan Komunikasi Bina Kasih/OMF, 2002.

St. Nikodemos of The Holy Mountain dan St. Makarios of Corinth. The Philokalia.
Volume 1. Diterjemahkan oleh G. E. H. Palmer, Philip Sherrard, dan Kallistos Ware. London: Faber and Faber, 1984.

- The Philokalia. Volume 2. Diterjemahkan oleh G. E. H. Palmer, Philip Sherrard, dan Kallistos Ware. London: Faber and Faber, 1984. The Philokalia. Volume 3. Diterjemahkan oleh G. E. H. Palmer, Philip Sherrard, dan Kallistos Ware. London: Faber and Faber, 1984.

The Philokalia. Volume 4. Diterjemahkan oleh G. E. H. Palmer, Philip Sherrard, dan Kallistos Ware. London: Faber and Faber, 1984.

Turner, T. Allan. A Study of Ephesians: A Verse by Verse Study of God's Eternal Purpose In An Through Jesus Christ. London: Allanita Press, 2002.

Wijaya, Hengki. "Pengenaan Manusia Baru Di Dalam Kristus: Natur, Proses, Dan Fakta Serta Implikasi Teologis Dan Praktisnya." Jurnal Jaffray Vol.14, No.1: April 2016.

Zuck, Roy B. dan Darrel L. Bock, A Biblical Theology Of The New Testament, terj. Paulus Adiwijaya. Malang: Gandum Mas, 2011. 